\title{
How Effective is the Electronic Dictionary in Sense Discrimination?*
}

Kim Hua Tan, Pusat Pengajian Bahasa dan Linguistik, Universiti

Kebangsaan Malaysia, Bangi, Selangor, Malaysia (kimmy@ukm.my)

\begin{abstract}
This article compares the efficacy of the electronic dictionary with that of the print dictionary in helping learners differentiate senses of polysemous words in dictionaries. An adaptation of the mixed methodology proposed by Johnson and Christensen (2004), the research design in this article encompasses a qualitative phase and a quantitative phase in the overall research study along the dimensions of time order and paradigm emphasis. The element of 'comparison' is included resulting in a design of four paired comparison groups: (1) Groupe-pre and Groupp-pre, (2) Groupe and Groupp, (3) Groupe-without and Groupe-with, and (4) Groupe-withoutLowMed and Groupe-withLowMed. Findings show that the electronic dictionary is effective in helping Low to Medium Proficient students (Group ${ }^{\text {-LowMed) }}$ in the electronic group after deliberate dictionary training in navigation and windows switching. This is indicated by improved scores regarding time taken (efficacy rate) and a significant correlation between actual efficacy and self-perceived efficacy. The results imply that dictionary users need to be given dictionary training based on specific problems they face. As a whole, however, the print dictionary group has higher efficacy than the electronic group but there was no discernible trend in the relationship between its actual efficacy and the self-perceived efficacy for both groups. This suggests that subjects' perceived efficacy beliefs are not good predictors of their performances.
\end{abstract}

Keywords: EFFICACY, ACTUAL EFFICACY, SELF-PERCEIVED EFFICACY, ELECTRONIC DICTIONARIES, PRINTED DICTIONARIES, POLYSEMOUS WORDS

Opsomming: Hoe doeltreffend is die elektroniese woordeboek by betekenisonderskeiding? Hierdie artikel vergelyk die doeltreffendheid van die elektroniese woordeboek met dié van die gedrukte woordeboek om aanleerders te help om die betekenisse van polisemiese woorde in woordeboeke te onderskei. Die navorsingsontwerp in hierdie artikel wat 'n aanpassing van die gemengde metodologie voorgestel deur Johnson en Christensen (2004) is, omvat ' $n$ kwalitatiewe fase en ' $n$ kwantitatiewe fase in die totale navorsingstudie langs die dimensies van tydsvolgorde en paradigmabeklemtoning. Die element van "vergelyking" wat ingesluit

* This article is based on research done for an unpublished Ph.D. Dissertation Sense Differentiation in Electronic and Print Dictionaries: A Comparative Study of Dictionary Efficacy, accepted by the Multimedia University, Cyberjaya, Selangor, Malaysia in 2007. It was presented as a paper at the Thirteenth International Conference of the African Association for Lexicography, organized by the Bureau of the Woordeboek van die Afrikaanse Taal, Stellenbosch, Republic of South Africa, 30 June-3 July 2008. 
word, het 'n ontwerp van vier in pare gerangskikte vergelykingsgroepe tot gevolg: (1) Groepe-pre en Groepp-pre, (2) Groepe en Groepp, (3) Groepe-sonder en Groepe-met, en (4) Groepe-sonderLaeMed en GroepemettaeMed. Bevindings toon dat die elektroniese woordeboek doeltreffend is deur Lae tot Medium Bekwame studente (Groepe-LaeMed) in die elektroniese groep te help na doelbewuste woordeboekopleiding in navigasie en vensteroorskakeling. Dit word getoon deur die verbeterde puntestande ten opsigte van tyd geneem (doeltreffendheidsmaatstaf) en die belangrike verband tussen werklike doeltreffendheid en selfgeskatte doeltreffendheid. Die resultate toon dat woordeboekgebruikers woordeboekopleiding gegee moet word wat berus op die spesifieke probleme waarvoor hulle te staan kom. As 'n geheel egter het die gedruktewoordeboekgroep 'n hoër doeltreffendheid as die elektroniese groep, maar daar was geen waarneembare tendens in die verhouding tussen die werklike doeltreffendheid en die selfgeskatte doeltreffendheid van altwee groepe nie. Dit dui daarop dat proefpersone se geskatte doeltreffendheidsbeskouings nie goeie voorspellers is van hul prestasies nie.

Sleutelwoorde: DOELTREFFENDHEID, WERKLIKE DOELTREFFENDHEID, SELFGESKATTE DOELTREFFENDHEID, ELEKTRONIESE WOORDEBOEKE, GEDRUKTE WOORDEBOEKE, POLISEMIESE WOORDE

\section{Introduction}

This article looks at the potential of the e-dictionary in comparison to the print dictionary in helping English as a Second Language (ESL) learners in deciphering meanings of words. By and large, in the area of English language studies, particularly in an ESL learning context, one pertinent concern would be whether dictionaries, electronic or otherwise, can help learners in mastering the second language and, in particular, whether dictionaries can help in directing learners to the right sense of the word in the dictionary. If the words concerned are polysemous, they are known to be difficult to ESL learners. Two general questions guided the determination of dictionary efficacy in this research:

(1) Do e-dictionaries have a higher efficacy in comparison to print dictionaries in providing easier access to sense differentiation?

(2) Is there a relationship between dictionary users' actual efficacy and their self-perceived efficacy?

\section{Past Research on Dictionary Comparison Studies}

User studies with respect to electronic dictionaries are frequently linked to second language comprehension. Nesi (2000) attempted to define and categorize the electronic dictionary, and consider the skills associated with its use for second language comprehension. She also reviewed previous research and put forward new research approaches that involved electronic dictionaries. 
In their research, Laufer (2000), Tono (2000) and Weschler and Pitts (2000) utilized controlled studies, comparing dictionary use under different conditions. Laufer (2000) investigated incidental vocabulary acquisition in two reading conditions: when unknown words are encountered in a paper text and glossed in the margin, and when they are read on computer screen and explained in an electronic dictionary. She collected data immediately after a reading task and again two weeks later. Results indicate that the electronic group performed significantly better than the paper text group. The superiority of the electronic dictionary over print was also pointed out by Leffa (1992a). The experiment, designed to test the performance of the electronic glossary as compared to traditional bilingual dictionaries, shows that the electronic glossary is superior, both in the number of idea units it allowed the subjects to retrieve from the text, and the time it demanded for the comprehension. Using the electronic glossary, the subjects read the passages faster and obtained more meaning from them. The difference was greatest with subjects whose language proficiency was lowest.

Speed is often perceived as an advantage of e-dictionaries but it has also been pointed out by Dillon (1992) that on-screen reading is $20 \%-30 \%$ slower than reading on paper in an experimental setting. It has been suggested that rapid reading must therefore be regarded as a deliberate activity. In a comparison of reading and skimming from 'books' and screens, Muter and Maurutto (1991) found that comprehension was higher when reading was done from screen. This could be accounted for by a speed-accuracy trade-off, as the skimming speed from paper was significantly faster than from screen. Another point to make is that different types of dictionaries are useful for different purposes. The electronic dictionary is conceivably useful for examinations, where speed is important, though the user might risk miscomprehension owing to the lack of sufficient explanation. On the other hand, the print dictionary is good for homework, where the aim is to learn, not to finish a task quickly.

Current efforts were also undertaken by Thinsan (2003) to compare the effects of the e-dictionary and paper-based dictionary in terms of the students' vocabulary learning retention and reading comprehension. Sharpe (1995: 50), who claims that 'one fear ... expressed by teachers ... is that the speed with which these electronic dictionaries retrieve information may not necessarily aid the memory's retention of the information for language learning purposes'. The reason for this, according to Sharpe, probably lies in the fact that while looking up a word in the print dictionary, the reader has to think about the word for a longer time since it takes longer to find the word than when working with the e-dictionary, but this point needs further research. In addition, the print dictionary enables the user to see the word family, thereby exposing him/her to more varieties and uses of the same word. The very fact that the user sees this variety can contribute to his/her retention of the meaning. It then appeared that print dictionaries can help to learn words, whereas most of the e-dictionaries help to find words. The retention of words is likely to be better with a print dictionary than with an e-dictionary. 
Tono (2000) reported the effects of three different electronic interfaces on EFL learners' look-up behaviour. Subjects performed language tasks under three conditions: with a paper dictionary, a traditional electronic dictionary, and two non-traditional electronic dictionaries. He investigated ESL learners' dictionary use and three factors that might influence it: the interfaces of electronic dictionaries, language translation tasks, and repeated exposure to the interface. The three interfaces of electronic dictionaries he examined were the traditional interface, the parallel interface and the layered interface. In the traditional interface, the information provided is similar to that of a print dictionary and it is easy to import the dictionary file into an electronic format. Information in the parallel interface is provided in a parallel bilingual translation format. All the words and phrases are stored separately in individual entries with their translation equivalents in a parallel format. In the layered interface, information is organized by a menu using tabs. Microstructurally, the organization is such that each tab offers different information, ranging from basic to complex. Results showed that, at the macrostructural level at least, electronic dictionaries provide quicker access to the target entry than the paper medium. The parallel interface allows faster search than the other two interfaces, even in the case of the complex search of idioms and compounds. Weschler and Pitts (2000) examined look-up speed, investigating whether electronic dictionaries are faster to use than print dictionaries. This study only looked at the efficiency of the dictionaries without considering accuracy. The three studies, nevertheless, highlighted the potential of the electronic dictionary in helping the comprehension of English as a second language.

Other e-dictionary related areas looked into by researchers are the e-dictionary as a teaching and learning tool (Hartmann and James 2001), dictionary skills (Tickoo 1989; Nesi 1999), the e-dictionary and its users (Atkins 1998; Cowie 1999; Dolezal and McCreary 1999; Hartmann 1999; Rundell 1999; Scholfield 1999), dictionary training (Berwick and Horsfall 1996; Nesi 1999; Wright 1998) and the structure of e-dictionaries (Burke 1998; Dodd 1989).

The earlier dictionary comparison studies tended to centre on the use of bilingual dictionaries. This is because ESL learners use them more for decoding than encoding. Leffa (1992b) compared the efficacy of electronic dictionary glossaries with the traditional paper dictionary on text comprehension in a translation task among 20 university students enrolled for a course in beginner English for academic purposes. The hypotheses were that the electronic dictionary users would spend less time with translation and have a better comprehension. The results indicated that the electronic dictionary users understood more of the passage $(86 \%)$ than the traditional dictionary users $(62 \%)$ and needed $50 \%$ less time to translate the passage. There was little attempt to investigate the students' actual look-up behaviour and its effects on their performance. Aust, Kelley and Roby (1993), for example, also compared the use of a hyper-reference source (electronic dictionary) and a conventional print dictionary. Measures included consultation frequency, study time, efficiency and 
comprehension. The efficacy of bilingual and monolingual dictionaries was also compared. But these studies again looked into the general behaviour patterns of learners in relation to reading skills with the help of glosses.

Clearly, dictionary comparison studies are not new, but very few of these deal with specific linguistic problems encountered by second language learners of English, such as the sense discrimination of polysemous words. There is an apparent need to add to this literature.

\section{Method}

The research design was a mixed method design comprising a paired experimental comparison group. This design utilized two control groups, the electronic group (Groupe) and the print group (Groupp). Subjects completed a task under two different conditions. Groupe used an electronic dictionary to complete a sense differentiation task and Group ${ }^{p}$ used a print dictionary to complete the same task. The research design was adapted from Johnson and Christensen's (2004) 2 × 2 matrix of qualitative and quantitative permutation but with changes so as to accommodate the element of 'comparison'. This is illustrated in Fig. 1 below. There are altogether four subdesigns of comparison groups that make up the whole research design for the study:

(1) Comparison Design of Groupe-pre and Groupp-pre (Groupe-pre: Electronic Group pre-study, Groupp-pre: Print Group pre-study);

(2) Groupe and Groupp (Groupe: Electronic Group, Groupp: Print Group);

(3) Groupe-without and Groupe-with (Groupe-without: Electronic Group without dictionary training, Group ${ }^{\text {ewith: }}$ Electronic Group with dictionary training);

(4) Groupe-withoutLowMed and Groupe-withLowMed (Groupe-withoutLowMed: Electronic Low Medium Proficiency Group without dictionary training, GroupewithLowMed; Electronic Low Medium Proficiency Group with dictionary training).

In each subdesign, collection of data for each paired group is weighted either towards the qualitative or quantitative aspects (paradigm emphasis) or according to sequential or concurrent methods (time emphasis).

There are altogether three stages in the study, a pre-study, a main study and an extended study, iterative steps occurring at the main study and the extended study. This is shown in Fig. 2 below, which is a flow chart of the overall comparison design according to the stages of study. At the main study and extended study stages, both data collection and data analysis, and subsequent iterations, proceeded in tandem, repeatedly referring back to each other: 'It involves a weaving back and forth between data and theory' (Bryman 2001: $10)$. 


\section{PARADIGM EMPHASIS}

\section{|TIME ORDER DECISION}

(A) 1st Comparison Group: Group ${ }^{\text {e-pre }}$ and Group ${ }^{\mathrm{p}-\text {-pre }}$

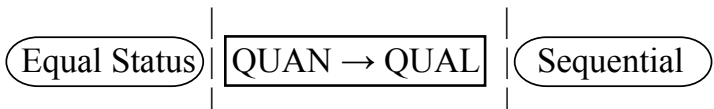

In the 1st subdesign, time order is sequential, both quantitative and qualitative phases are of equal status

(B) 2nd Comparison Group: Group ${ }^{\mathrm{e}}$ and Group ${ }^{\mathrm{p}}$

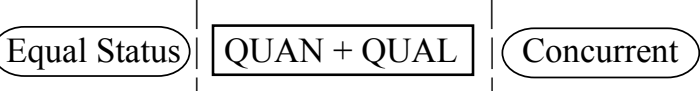

In the 2nd subdesign, time order is concurrent, both quantitative and qualitative phases are of equal status

(C) 3rd Comparison Group: Group ${ }^{\text {e-with }}$ and Group ${ }^{\text {e-without }}$

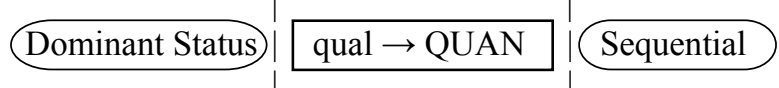

In the 3rd subdesign, time order is sequential, the overall study is dominantly quantitative preceded by a qualitative phase

(D) 4th Comparison Group: Group ${ }^{\text {e-withLowMed }}$ and Group ${ }^{\text {e-withoutLowMed }}$

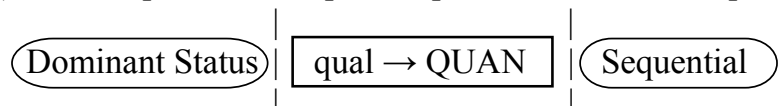

In the 4th subdesign, time order is again sequential, dominantly quantitative but preceded by a qualitative phase

Fig. 1: Mixed-Method Comparison Design for Dictionary Efficacy Study (Tan 2007).

Key Notation: QUAL and qual both stand for qualitative research; QUAN and quan both stand for quantitative research; capital letters denote priority or increased weight; lower-case letters denote lower priority or weight; a plus sign $(+)$ indicates the concurrent collection of data; an arrow $(\rightarrow)$ represents a sequential collection of data, for example qual $\rightarrow$ QUAN indicates dominant status, sequential design where the overall study is primarily quantitative but is preceded by a qualitative phase. 


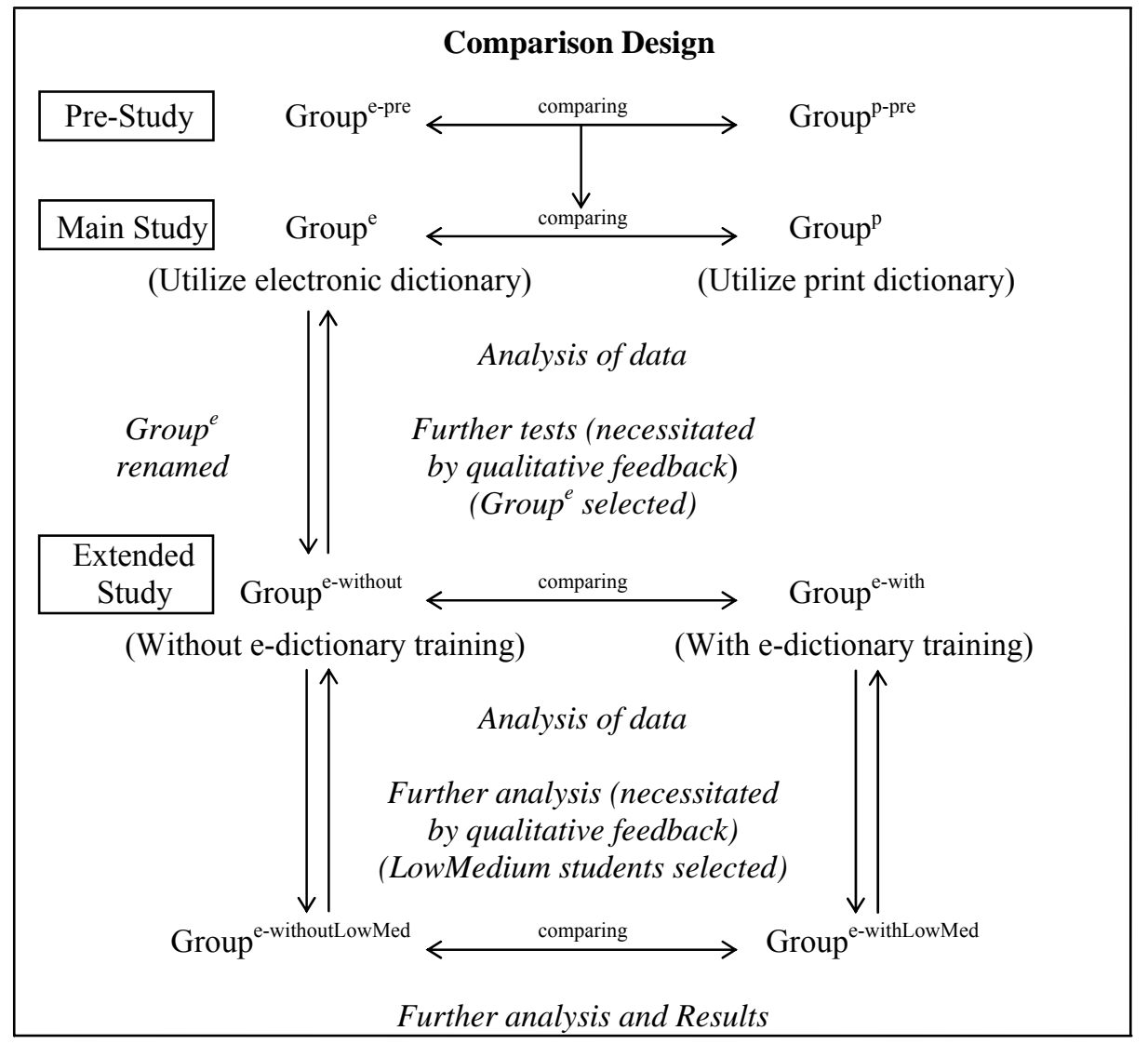

Fig 2: Comparison Design of Groupe-pre and Groupp-pre; Groupe and Groupp, Group ${ }^{\mathrm{e}-w i t h o u t}$ and Group ${ }^{\mathrm{e}-w i t h} ;$ Group ${ }^{\mathrm{e}-\text { withoutLowMed }}$ and Group ${ }^{\mathrm{e}-w i t h L o w M e d}$

(Tan 2007)

The iterative nature of this study indicated two further significant steps in the procedure. Firstly, data analysis in the main study pointed towards and necessitated a pre- and a post-test for Groupe with dictionary training as a treatment procedure. This was to determine whether dictionary training was another possible factor in determining the subjects' efficacy. Secondly, data also indicated that further analysis on a selected group of subjects from Groupe, Low to Medium Proficient students (Group ${ }^{\mathrm{e}-\text { LowMed }}$ ) was pertinent and necessary.

Efficacy is the ability to complete a task accurately, independently and quickly. In this study, efficacy had two variants, namely actual efficacy and self-perceived efficacy. Actual efficacy is indicated by scores obtained over time. (See research instrument WoSIT below.) It is quantitatively measured. Self-perceived efficacy is the subjects' belief in their capabilities to produce effects, to effectively control specific events in their lives (Bandura 1997). In this 
study, self-perceived efficacy refers to how users perceived the use of the dictionaries indicated by the perceptual ratings of the ease of use, satisfaction and usability of the dictionaries. (See research instrument Retro below.) The argument is that if subjects find the dictionaries easy, useful and satisfactory, by implication they also perceive their capability to be high, hence high self-perceived efficacy.

\section{Subjects}

The participants were university undergraduates majoring in English Language Studies at the Universiti Kebangsaan Malaysia, a public university in Malaysia. An electronic dictionary group, Groupe, consisting of 154 participants and a print dictionary group, Groupp, comprising 150 participants were formed from the total of 304 undergraduates selected for this study. (For Participants' Profile, see Table 1.) The proficiency level of the students was determined by their Malaysian University Entrance Tests (MUET) bandscores.

Table 1: Student Profile according to MUET bandscores

\begin{tabular}{|l|c|l|c|}
\hline \multicolumn{2}{|c|}{$\begin{array}{c}\text { Electronic Dictionary } \\
\mathrm{n}=154 \text { participants }\end{array}$} & \multicolumn{2}{c|}{$\begin{array}{c}\text { Print Dictionary } \\
\mathrm{n}=150 \text { participants }\end{array}$} \\
\hline MUET Band & \% of students & MUET Band & $\%$ of students \\
\hline 6 High High & - & 6 High High & - \\
\hline 5 Low High & 22.08 & 5 Low High & 20.7 \\
\hline 4 High Medium & 36.4 & 4 High Medium & 66.7 \\
\hline 3 Low Medium & 35 & 3 Low Medium & 12.56 \\
\hline 2 High Low & 6.52 & 2 High Low & 0.04 \\
\hline 1 Low Low & - & 1 Low Low & - \\
\hline
\end{tabular}

\section{Research Instruments}

Three main research instruments were used in this study.

(1) WoSIT (Word Sense Identification Test). WoSIT consisted of ten sense identification items designed to test learners' ability to select the right sense or meaning of the underlined word in the test item. A slot for recording the total time taken to complete the whole task was also included at the end of the page. Students were required to identify and circle the correct sense of a particular word in a sentence from the given range of senses of that word. This task was comparable to the written component (Editing section) of the UETESOL (University Entrance Test in English for Speakers of Other Languages) previously known as NEAB (Northern Examinations and Assessment Board) that required candidates to match a word in context with one of several meanings in a given 
dictionary entry. UETESOL is an established English proficiency entrance requirement equivalent or similar to IELTS or TOEFL for students enrolling for courses in British universities.

(2) Retro. The Retro Sheets are self-completed questionnaires comprising two parts. Part A is a semantic differential scale. The items in the scale were designed to gauge the learners' perceptions and attitudes toward the use of the two types of dictionaries, particularly their perceived ease, satisfaction and usability by looking at their perceptual ratings. In Part B, the short response questions aimed to elicit information on the difficulties the participants faced in using the electronic dictionary for deciphering the senses of the words.

(3) COBUILD3. Both the print and electronic versions of the third edition of Collins COBUILD English Dictionary for Advanced Learners (2001), designated COBUILD3, were used as references during the completion of the task in WoSIT. The electronic version of COBUILD3, called Collins COBUILD on CD-ROM, was based on the printed reference work. They are similar microstructurally (in terms of contents and sequencing of entries) but differ macrostructurally (in terms of means of access and navigation), because both print and electronic formats dictate different routes.

\section{Findings}

Generally, results of the study indicated that Groupp (print dictionary group) performed better in the task than Group (electronic dictionary group), the difference in efficacy being significant. This implied that the print dictionary was more effective in assisting subjects in sense differentiation than the electronic dictionary. Three reasons were put forward as possible factors affecting their performance. These were (1) familiarity with the print format for Groupp, (2) the nature of the test materials and (3) a lack of exposure to the electronic format for Groupe.

The efficacy of Groupp could be attributed to the fact that subjects were more familiar with the print format or paper-based dictionary and therefore used less time to complete the task. Actual efficacy was measured through performance indicated by accuracy rate (scores obtained over time). As time taken was of the essence, it is conceivable that Groupp had the upper hand in the task owing to familiarity with the dictionary format. Most Malaysian students have earlier experiences with print dictionaries in their schooldays in comparison to electronic dictionaries which only appeared locally in educational institutions less than a decade ago. It could be the case where there is a speed-accuracy trade-off. This refers to participants' trading of increases in speed for decreases in accuracy (and vice versa) over a substantial range (Lohman 1989). Speed is an advantage for Groupe because of the electronic medium while familiarity with the print format helped in accelerating the look-up proc- 
ess for Groupp but if subjects were to prioritize accuracy to the exclusion of speed, then these are not advantages any more.

The nature of the materials used in the experimental task in this study could also have affected the relative performance of Groupe and Groupp. The fact that both the experimental test and the reference dictionary used by Groupp were in print mode could have contributed to Groupp's better performance. On the other hand, Groupe used the e-dictionary which was in a different mode from the printed experimental test. Though some of the subjects had indicated that they had no problems reading from a screen, it is worthwhile reiterating here that research had shown that reading from a screen in an experimental setting is $20 \%$ to $30 \%$ slower than reading from paper (Dillon 1992) which could have accounted for Groupe's lower efficacy. Although using an electronic dictionary in the completion of print work was also very much a real-life task, the differing modes or formats could have affected their performances. Other possible factors were familiarity with the computer keyboard, or even typing speed, though these factors were deemed insignificant because the words the subjects were required to type were on average only six letters in length.

Data had also suggested that the poor performance of Groupe could have been attributed to lack of exposure and training in using the electronic dictionary. Qualitative input indicated that more preparation was needed for Groupe before they attempted the task. Of Groupe, $25 \%$ claimed unfamiliarity with the format of the electronic dictionary, particularly navigational features. Although there was a short orienting phase before the collection of data, it was clearly not enough. Further investigation suggested that the orienting exercise consisting of a 10-minute exposure for Groupe was inadequate. Apparently, the novelty effect was far more overwhelming for most of the students in Groupe than Groupp. Only $0.9 \%$ of the subjects in Groupp indicated that they had difficulties using the print dictionary as a reference tool to complete the task. In comparison to Groupe which had 25\%, 0.9\% for Groupp was considered minimal.

Deliberate instruction or training, however, did not appear to improve the efficacy of Groupe. Although mean efficacy was higher after training, the results of the paired t-test showed that there was no significant difference in dictionary efficacy between Groupe-without and Groupe-with with the introduction of training.

However, data from the mean rating of the parameters of 'ease', 'satisfaction' and 'usefulness' indicated that $25 \%$ of the subjects, particularly those from the Low Medium Proficient group, Groupe-LowMed, showed encouraging responses and better perceptual ratings after more exposure to dictionary training. There was also improvement in their scores and efficacy. Training seemed to have positive effects on Groupe-withLowMed.

Subsequent analysis confirmed that deliberate instruction had in fact made a difference to this group of subjects and the e-dictionary was instrumental in helping them with their task. The pre-post paired t-test carried out 
on Groupe-LowMed is a commonly used inferential statistic, mainly intended to determine whether scores before training (pre-test) are significantly different from scores after training (post-test). Results from the analysis of the paired $t-$ test on this particular paired group indicated a significant difference in the means of the efficacy between both groups, with the means of Groupe-withLowMed higher than Groupe-withoutLowMed. It appeared that although training did not make a significant difference to the whole electronic group, Group ${ }^{\mathrm{e}}$, it did improve the efficacy of a subgroup, Groupe-withLowMed. This suggested that less proficient students may need more deliberate dictionary instruction, particularly when it comes to new modalities. Highly proficient students are generally better and quicker at grasping new ideas and skills regardless. Data pointed towards the fact that unnecessary training may have a less favourable effect on them. Training evidently should be tailored to the particular group of students lest it should be insufficient for the less proficient and needless for the more proficient.

\section{Conclusion}

In summary, the results of the study indicated that Groupp performed better in the task than Groupe and the difference in efficacy was significant. The three reasons being familiarity with the print format for Groupp, lack of exposure to the electronic format for Group and the nature of the test materials were proposed as possible factors affecting their performance. Even after training, results indicated that there was no significant difference in dictionary efficacy between the electronic group for both Groupe-without and Groupe-with. As the qualitative data indicated, it appeared that training was unnecessary for the whole Groupe. It benefited only a small subgroup of Groupe, Groupe-LowMed. Subsequently, there was a significant difference in efficacy for Group ${ }^{\mathrm{e}-w i t h o u t L o w-~}$ Med and Groupe-withLowMed after training. It appeared that deliberate instruction was one of the factors affecting their performance.

The results indicated that except for Groupe-withLowMed, there was a weak correlation between actual efficacy and perceived efficacy within groups: Groupe, Groupp, Groupe-without, Groupe-with and Group ${ }^{\mathrm{e}-\text {-withoutLowMed }}$. It appeared that all the groups had higher confidence in their performance evidenced by the above average self-rating of their own performance. Generally, the relationship was weak to poor between their actual performance and their perception of their performance. Group ${ }^{\mathrm{e}-w i t h L o w M e d}$ comparatively had a stronger relationship between its actual efficacy and perceived efficacy. There was, however, a discernible positive trend in the relationship between the actual efficacy and perceived efficacy for all the groups.

In conclusion, it is perhaps pertinent to say that expectations of the utility and functionality of electronic dictionaries among learners, particularly those of second language learners of English, have risen over the years. What this study has demonstrated is that both electronic dictionaries and print diction- 
aries have merits. The two different modes are suitable for different purposes. It is perhaps too early to say that the electronic dictionary has the capability to replace the print dictionary as Sharpe (1995: 49) puts it: 'It is my view that the advantages of the electronic dictionary and the familiarity of today's young people with electronic devices will eventually relegate the printed notion of "dictionary" to a secondary sense.'

\section{References}

Atkins, B.T.S. (Ed.). 1998. Using Dictionaries. Studies of Dictionary Use by Language Learners and Translators. Lexicographica. Series Maior 88. Tübingen: Max Niemeyer.

Aust, R., M.J. Kelley and W.B. Roby. 1993. The Use of Hyper-reference and Conventional Dictionaries. Educational Technology Research and Development 41(4): 63-73.

Bandura, A. 1997. Self-efficacy. The Exercise of Control. New York: W.H. Freeman.

Berwick, G. and P. Horsfall. 1996. Making Effective Use of the Dictionary. London: Centre for Information on Language Teaching and Research.

Bryman, A. 2001. Social Research Methods. Oxford: Oxford University Press.

Burke, S.M. 1998. The Design of Online Lexicons. Unpublished Master's Thesis. Evanston, IL., Northwestern University. http://www.netadventure.net/ sburke/bounce.cgi/ma/.

Cowie, A.P. 1999. English Dictionaries for Foreign Learners: A History. Oxford: Oxford University Press/Clarendon Press.

Dillon, A. 1992. Reading from Paper versus Screens: A Critical Review of the Empirical Literature. Ergonomics 35(10): 1297-1326.

Dodd, S. 1989. Lexicomputing and the Dictionary of the Future. James, G. (Ed.). Lexicographers and their Works: 83-93. Exeter: University of Exeter Press.

Dolezal, F.T. and D.R. McCreary. 1999. Pedagogical Lexicography Today: A Critical Bibliography on Learners' Dictionaries with Special Emphasis on Language Learners and Dictionary Users. Lexicographica. Series Maior 96. Tübingen: Max Niemeyer.

Hartmann, R.R.K. (Ed.). 1999. Dictionaries in Language Learning. Recommendations, National Reports and Thematic Reports from the Thematic Network Project in the Area of Languages, Sub-project 9: Dictionaries. Berlin: Freie Universität. http://www.fu-berlin.de/elc/TNPproducts/SP9dossier. doc.

Hartmann, R.R.K. and G. James. 2001. Dictionary of Lexicography. London/New York: Routledge.

Johnson, B., and L.B. Christensen. 2004. Educational Research: Quantitative, Qualitative, and Mixed Approaches. Boston: Allyn and Bacon.

Laufer, B. 2000. Electronic Dictionaries and Incidental Vocabulary Acquisition: Does Technology Make a Difference? Heid, U., S. Evert, E. Lehmann and C. Rohrer (Eds.). 2000. Proceedings of the Ninth EURALEX International Congress, EURALEX 2000, Stuttgart, Germany, August 8th12th, 2000: 849-854. Stuttgart: Institut für Maschinelle Sprachverarbeitung, Universität Stuttgart.

Leffa, V.J. 1992a. Reading with an Electronic Glossary. Computers and Education 19(3): 285-290.

Leffa, V.J. 1992b. Making Foreign Language Texts Comprehensible for Beginners: An Experiment with an Electronic Glossary. System 20: 63-73. 
Lohman, D.F. 1989. Individual Differences in Errors and Latencies on Cognitive Tacks. Learning and Individual Differences 1: 179-202.

Muter, P. and P. Maurutto. 1991. Reading and Skimming from Computer Screens and Books: The Paperless Office Revisited? Behaviour and Information Technology 10(4): 257-266.

Nesi, H. 1999. The Specification of Dictionary Reference Skills in Higher Education. Hartmann, R.R.K. (Ed.). 1999. Dictionaries in Language Learning. Recommendations, National Reports and Thematic Reports from the Thematic Network Project in the Area of Languages, Sub-project 9: Dictionaries: 53-67. Berlin: Freie Universität. http://www.fu-berlin.de/elc/TNPproducts/SP9 dossier. doc.

Nesi, H. 2000. The Use and Abuse of EFL Dictionaries. How Learners of English as a Foreign Language Read and Interpret Dictionary Entries. Lexicographica. Series Maior 98. Tübingen: Max Niemeyer.

Rundell, M. 1999. Dictionary Use in Production. International Journal of Lexicography 12(1): 35-53.

Scholfield, P. 1982. Using the English Dictionary for Comprehension. TESOL Quarterly 16(2): 185194.

Scholfield, P. 1999. Dictionary Use in Reception. International Journal of Lexicography 12 (1): 13-34.

Sharpe, P. 1995. Electronic Dictionaries with Particular Reference to the Design of an Electronic Bilingual Dictionary for English-speaking Learners of Japanese. International Journal of Lexicography 8(1): 39-54.

Tan, K.H. 2007. Sense Differentiation in Electronic and Print Dictionaries: A Comparative Study of Dictionary Efficacy. Unpublished Ph.D. Dissertation. Multimedia University, Cyberjaya, Selangor.

Thinsan, S. 2003. Effects of Electronic Dictionary on Vocabulary Retention and Reading Comprehension of EFL Undergraduate Students in a Thai University. Unpublished Master's Thesis. Language Education, Indiana University.

Tickoo, M.L. (Ed.). 1989. Learners' Dictionaries: State of the Art. Singapore: SEAMEO Regional Language Centre.

Tono, Y. 2000. On the Effects of Different Types of Electronic Dictionary Interfaces on L2 Learners' Reference Behaviour in Productive/Receptive tasks. Heid, U., S. Evert, E. Lehmann and C. Rohrer (Eds.). Proceedings of the Ninth EURALEX International Congress, EURALEX 2000, Stuttgart, Germany, August 8th-12th, 2000: 855-862. Stuttgart: Institut für Maschinelle Sprachverarbeitung, Universität Stuttgart.

Weschler, R. and C. Pitts. 2000. An Experiment Using Electronic Dictionaries with EFL Students. The Internet TESL Journal 6(8). http://www.aitech.ac.jp/ iteslj/Articles/Weschler-Electro Dict.html.

Wright, A. 1998. Dictionaries. Resource Books for Teachers. Oxford: Oxford University Press. 